\title{
Screening Twenty Cowpea (Vigna unguiculata (L.) Walp) Genotypes for Resistance to Thrips (Megalurothrips sjöstedti) in Burkina Faso
}

Sidibé Hamadou (Corresponding author)

Environmental Agricultural and Research Center of Training /INERA/Burkina Faso E-mail: hamadousidibe22@yahoo.fr/hamasegua22@gmail.com Batiéno Benoit Joseph

Environmental, Agricultural and Research Center of Training /INERA/Burkina Faso Email: bbjersi2003@yahoo.fr

Tignigré Jean Baptiste De La Salle

World Vegetable Centre (AVRDC), Bamako BP 320, Mali

Email: racinetignegre@yahoo.com

Kusi Francis

Savanna Agricultural Research Institute, Tamale P.O. Box 52, Ghana

Email: onkufra@yahoo.co.uk

Ouédraogo Tinga Jeremy

African Biosafety Network for Expertise (ABNE), Dakar BP 17204, Senegal

Email: jt.ouedraogo@nepadbiosafety.net

Sawadogo Mahamadou

Genetic and plant breeding, University of Ouagadougou I PR Joseph KI-ZERBO,

Ouagadougou, Burkina Faso

Email: sawadogomahamadou@yahoo.fr

Received: October 17, 2018

doi:10.5296/jas.v6i4.13964
Accepted: November 18, 2018

URL: https://doi.org/10.5296/jas.v6i4.13964 


\section{Abstract}

Losses caused by flower thrips in cowpea are important. These pests can cause from $60 \%$ to total crop yield loss. There is, therefore, an urgent need to address this issue. This work has been undertaken to identify sources of resistance to thrips in cowpea. Twenty cowpea genotypes were screened at Kamboinsé research station under improve netting in pots. The number of aborted flowers per line, the percentage of damage to flowers and stipules, and the number of thrips per genotype were evaluated. The results revealed the existence of six genotype of cowpea resistant to thrips. Among these genotypes three are already known thrips resistant lines (TVU1509, TVx3236 and Sanzi). Moreover, Sanzi showed interesting potentialities that maybe exploited. The new identified lines are Nafi, variety popularized in 2012 and variety KVx780-3 which is being popularized. The KVx165-14-1 (old popular variety) showed sources of tolerances while the KN1 genotype was susceptible to thrips. In another hand, all the wild genotypes showed high susceptibility to thrips.

Keywords: cowpea, Vigna unguiculata, genotypes, Megalurothrips sjostedti, lines resistances

\section{Introduction}

Cowpea is an important food crop in sub-Saharan Africa, particularly in the arid savannah zones of West Africa (Murdock et al., 2008). It is a valuable source of vegetable protein and vitamins for humans and animal fodder. The leaves and immature pods are consumed as vegetables (Pasquet et al., 1998).

Cowpea is a good crop for soil improvement by fixing atmospheric nitrogen. For Ennin-Kwabiah and Osei-Bonsu (1993), cowpea can fix 30-125 Kg of nitrogen per hectare in the soil and also serves as a residue, which benefits the succeeding crops .It can also provide substantial income for producers and processors.

However, cowpea production is facing some biotic and abiotic constraints. The major biotic constraints are insect pests. They attack cowpea at all growth stages. The main insect pests of cowpea in Africa are aphids, flower bud thrips, pod borer, pod bugs and bruchids (Dabiré et al 2001). Among these insects, thrips (Megalurothrips sjostedti) are responsible for very important economic losses. They attack buds, racemes and flowers causing premature abortion of these reproductive organs. Yield losses, due to thrips, ranged between $20-100 \%$ have been reported (Singh et $a l, 1980)$. Their damage can sometimes lead to change a cowpea nutritional composition (Alabi et al, 2003). Several control methods have been developed. Like the chemical method, he has immediate results but he is dangerous for the human, animal and environment health. In long-term, using the chemical method can be responsible to the insects' resistance. The use of resistant varieties is more advantageous for the health economic and environment.

Sanzi, TVu1509, Sewe and Moussa local, IT90K-277-2, IT91K-180, KVx404-8-1 and TVx3236 have been reported to be resistant to flowers bud thrips by Alabi et al. (2003). These known sources of resistance mentioned above can be considered as good breeding material (donors) for the breeding program.

However, these resistant varieties do not meet the preference of producers and consumers in 
Burkina Faso, therefore it is crucial to screen the local germplasm in order to determine the status of released varieties in terms of resistance / tolerance to thrips. The insect (Thrips) causes enormous damage to the production of cowpea in Burkina Faso and that no real study has been made in this direction. Screening of the local germplasm can lead to the identification of preferred varieties well adapted to the environment and combining resistance/tolerance to thrips.

The objective of this work was to identify levels of resistance in twenty (20) cowpea cultivars to $M$. sjostedti by screening the local germplasm in Burkina Faso under sleeve cage.

\section{Materials and Methods}

\subsection{Plant Material and Experimental Design}

The study was conducted in pots under a sleeve cage at INERA/Kamboinsé during the rainy season 2016-2017. Twenty genotypes were used including two controls Sanzi and KN1, resistant and susceptible respectively (table 1).The experimental design was the randomized complete block design (RCBD) with three replications. Each replication consists of 20 pots. The pots were filled with a mixture of sand and topsoil. Each line was represented by a pot corresponding to the experimental unit. Two to three seeds were initially planted in the pots and thinned to one plant per pot after emergence. After infestation, the plants were protected from other types of insects with improve netting. Each plant was infested with twenty (20) thrips at flower bud initiation and /or the appearance of the first flower.

Table 1. Twenty genotypes used for thrips screening

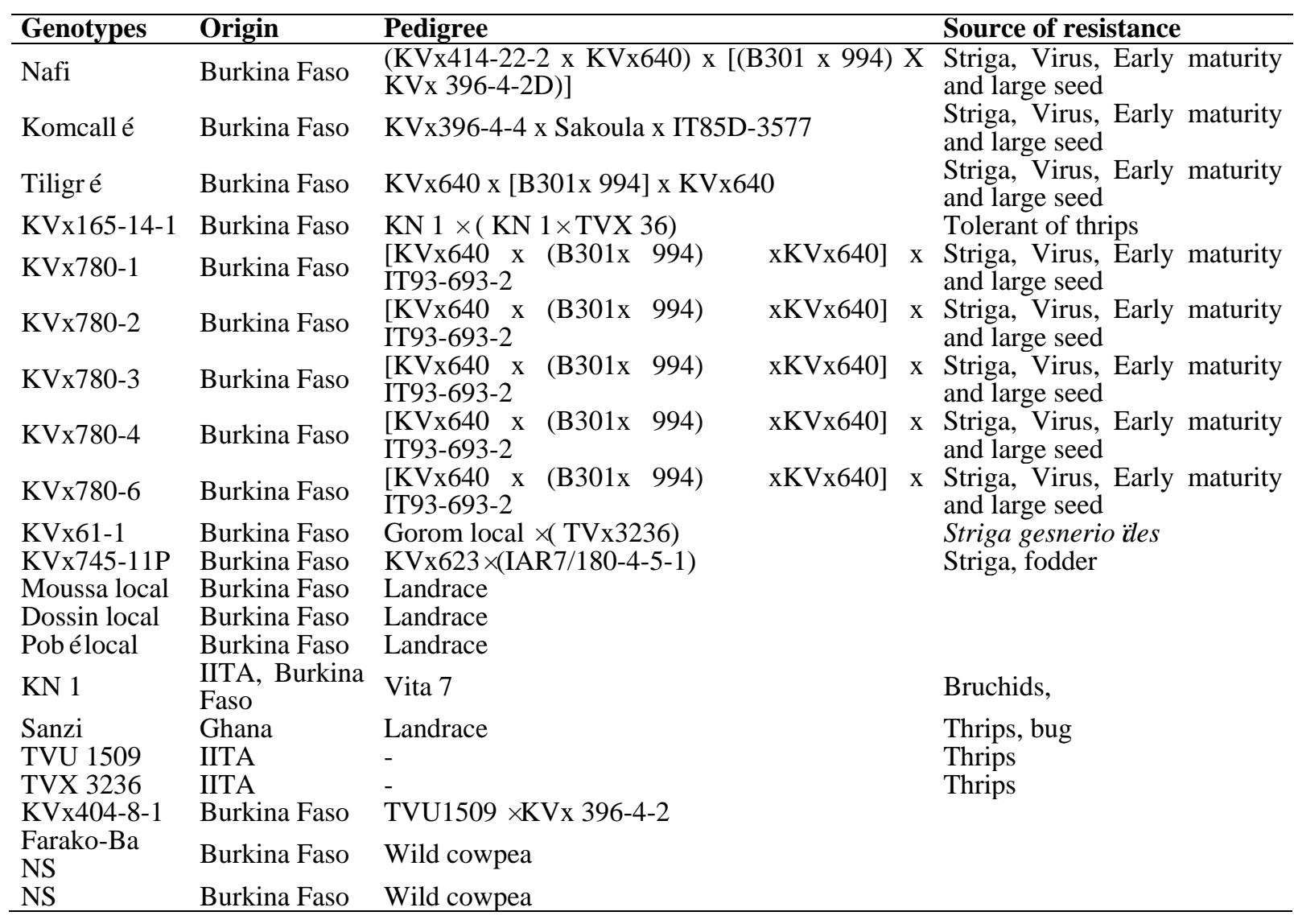




\subsection{Thrips Rearing}

Before infestation, the thrips were reared in the laboratory. The variety $\mathrm{KN}-1$ was planted at different sowing dates to ensure continuous flower production and thrips population development. The peduncles were cut into sizeable pieces and sprinkled with a little amount of water on a tissue paper. Make a bundle of peduncles by wrapping them in the damp tissue paper. Ensure that only the base of the peduncles is covered with the tissue. Using the pair of scissors, cut out the brown paper. Fold it in diagonally to make a pouch. Secure the ends with a tape. Put the bunch of peduncles into this pouch. Pour out the sampled flowers onto a laid white sheet on the laboratory table. Gently tease out the petals of the flowers to reveal the thrips. With the aid of an aspirator, collect the thrips and place them in the pouch containing the peduncles. Sample as many thrips as possible into the pouch and seal the opened end with a masking tape.

Place the sealed pouch into a plastic container, cover the container with a white cotton cloth and secure with a plastic band. Leave the set up on a table at room temperature. After every 48 hours replace the old peduncles with new ones and if needed infest with more thrips.

\subsection{Artificial Infestation}

Sample 20 thrips into a vial and plug the opening of the vial with cotton to prevent the thrips from escaping. Place the vial on an ice pack or the fridge for approximately 3-5 minutes to knockdown the thrips to ease their handling during infestation.

Infest each plant with the 20 thrips by placing the thrips on the lower leaves or near or on the flower buds. Cover the infested plant with an insect-proof sleeve cage to prevent the thrips from escaping and also ensure no further external environmental influence. (Figure 1) 


\section{Macrothink}
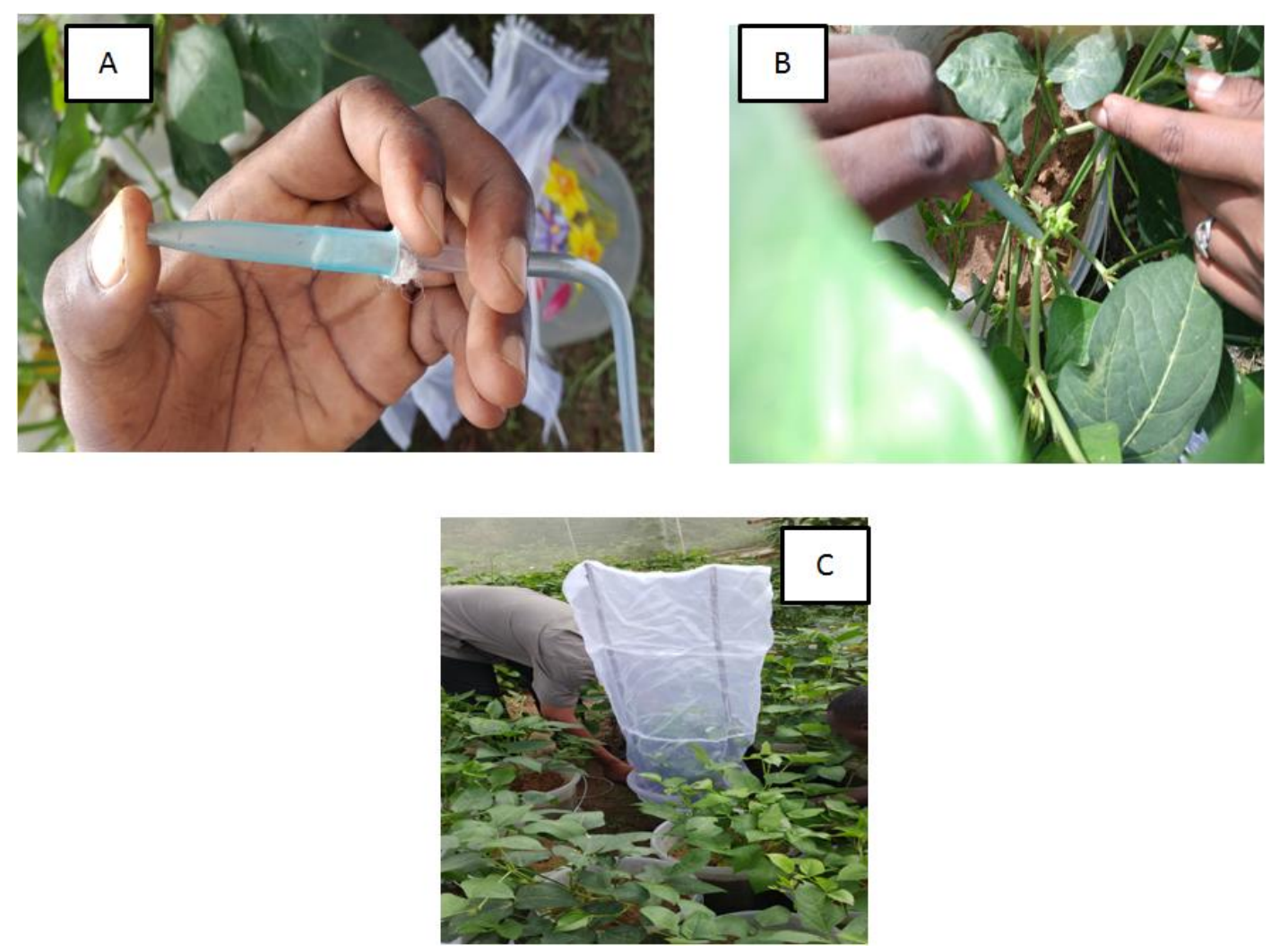

Figure 1. A: collection of twenty (20) thrips; B: Infest each plant with the 20 thrips; C: Cover the infested plant with an insect-proof sleeve cage

\subsection{Data Collection and Analysis}

The data were collected base on the scale described previously by Jackai and Singh (1988). After the infestation by twenty (20) thrips on each pot, a period of ten (10) days is observed before the collection and counting of thrips of the infested plants begins. This period is consistent to observe a change in the density of thrips on infested plants.

\subsubsection{Plant Damage}

- The number of buds aborted per plant

- The number of aborted flowers per plant

- The number of thrips per plant

\subsubsection{Flower Damages(Figure 2)}

1: No browning/drying of flowers (highly resistant)

3: Initiation of browning of the flowers (resistant)

5: Distinct browning/drying of flowers (moderately resistant)

7: Serious browning/drying of flowers (susceptible)

9: heavy browning/drying of flowers (highly susceptible) 


\section{Macrothink}

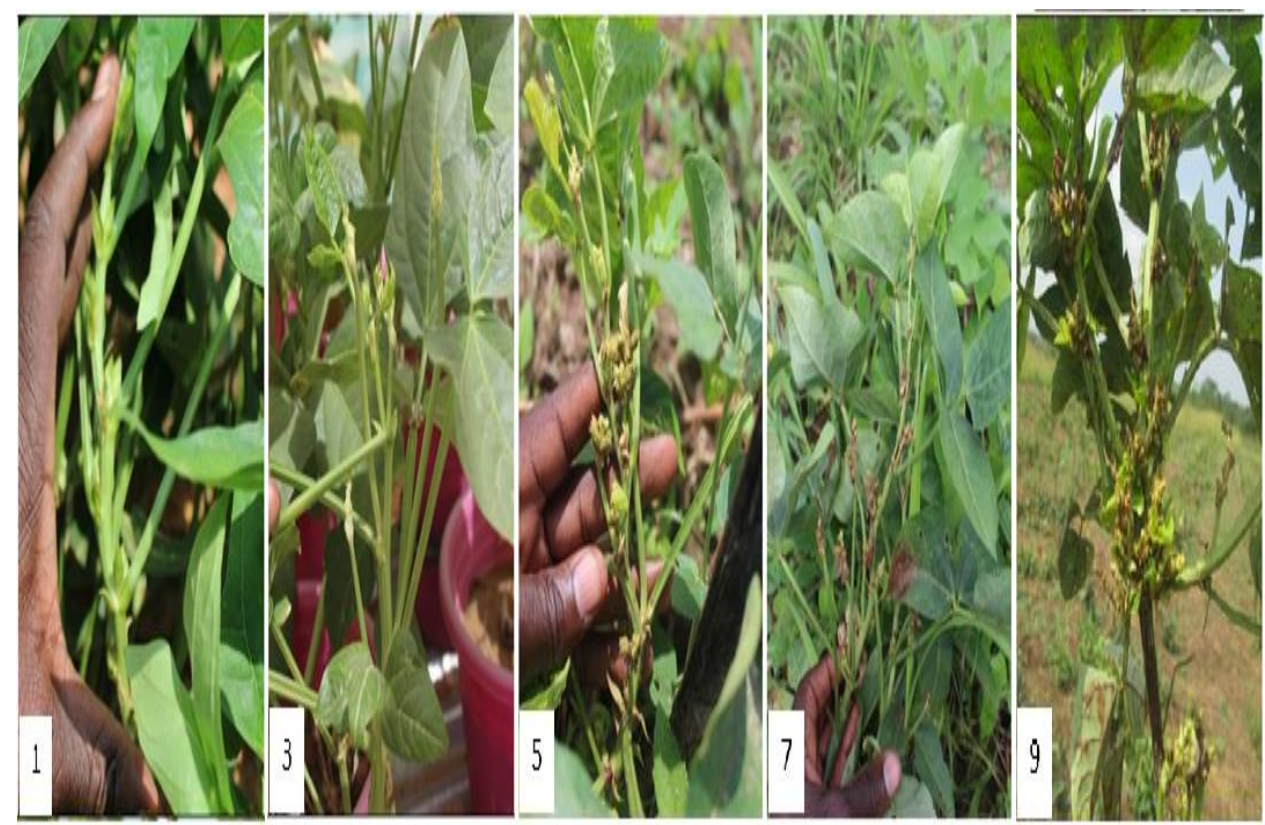

Figure 2. Adapted scale used for scoring plant damage

\subsubsection{Count number of Thrips Per Plant}

Balde and Diop (1995); Balde (1997) method was used for thrips count. Five flowers were Collected once a week from each plant and place in plastic via containing $30 \%$ alcohol.

In the laboratory, The content of each vial was transfer into a white petri dish. Carefully tease out the petals of the flowers to reveal the thrips and count their number with the aid of a hand lens. Alternatively, the flowers are dissected in the laboratory and submerged in a plastic vial containing $30 \%$ alcohol. It should be noted that the alcohol is added in advance of the red dye. For the preparation of the solution one liter of alcohol, $4.7 \mathrm{ml}$ of the dye are required. The plastic vial is finally placed under the magnifying lamp for observation.

\subsection{Data Analysis}

Statistical analysis were done using the BMS 3.09 and XLSTAT 2015software.The LSD test was used for mean separation at the $5 \%$ confidence level.

\section{Results and Discussion}

\subsection{Results}

The results for all the parameters studied were significantly different. These parameters were:

- The number of buds aborted per plant

- The number of aborted flowers per plant

- The number of thrips per plant

- Flower damages 
Table 2. Response of cowpea varieties to Megalurothrips sjöstedti

\begin{tabular}{lllll}
\hline Varieties & Thrips number & Flowers damage & Flowers abortion & Buds abortion \\
\hline Dossin local & $2.000 \mathrm{a} \pm 1.15$ & $1.667 \mathrm{ab} \pm 0.88$ & $7.000 \mathrm{ab} \pm 5.57$ & $103.33 \mathrm{a} \pm .87 .0$ \\
Gourgou & $2.333 \mathrm{a} \pm 1.20$ & $2.000 \mathrm{ab} \pm 1.00$ & $10.000 \mathrm{ab} \pm .0 .57$ & $40.33 \mathrm{a} \pm .23 .0$ \\
KN 1 & $14.333 \mathrm{a} \pm 3.84$ & $6.333 \mathrm{~b} \pm 1.20$ & $11.000 \mathrm{ab} \pm .2 .65$ & $66.67 \mathrm{a} \pm .48 .0$ \\
Komcalle & $6.667 \mathrm{a} \pm 3.67$ & $3.667 \mathrm{ab} \pm 0.67$ & $15.333 \mathrm{ab} \pm .1 .66$ & $35.67 \mathrm{a} \pm .16 .0$ \\
Kvx165-14-1 & $12.000 \mathrm{a} \pm 2.52$ & $5.333 \mathrm{ab} \pm 0.88$ & $7.000 \mathrm{ab} \pm .3 .06$ & $61.00 \mathrm{a} \pm .45 .0$ \\
Kvx404-8-1 & $5.000 \mathrm{a} \pm 2.52$ & $3.333 \mathrm{ab} \pm 0.88$ & $12.000 \mathrm{ab} \pm 1.53$ & $59.67 \mathrm{a} \pm .32 .0$ \\
Kvx61-1 & $4.667 \mathrm{a} \pm 2.40$ & $2.333 \mathrm{ab} \pm 1.20$ & $10.000 \mathrm{ab} \pm 5.03$ & $27.67 \mathrm{a} \pm .0 .0$ \\
Kvx745-11P & $4.000 \mathrm{a} \pm 2.65$ & $2.333 \mathrm{ab} \pm 1.45$ & $5.333 \mathrm{ab} \pm .2 .33$ & $90.67 \mathrm{a} \pm .61 .0$ \\
Kvx780-1 & $9.667 \mathrm{a} \pm 8.21$ & $3.667 \mathrm{ab} \pm 2.03$ & $9.000 \mathrm{ab} \pm .1 .15$ & $30.67 \mathrm{a} \pm .16 .0$ \\
Kvx780-3 & $4.000 \mathrm{a} \pm 2.65$ & $2.333 \mathrm{ab} \pm 1.45$ & $6.000 \mathrm{ab} \pm .1 .73$ & $31.33 \mathrm{a} \pm .24 .0$ \\
Kvx780-6 & $6.000 \mathrm{a} \pm 1.00$ & $3.333 \mathrm{ab} \pm 0.33$ & $9.333 \mathrm{ab} \pm .2 .73$ & $42.00 \mathrm{a} \pm .26 .0$ \\
Moussa local & $2.000 \mathrm{a} \pm 1.15$ & $1.667 \mathrm{ab} \pm 0.88$ & $3.000 \mathrm{ab} \pm .1 .53$ & $96.33 \mathrm{a} \pm .71 .0$ \\
Nafi & $3.000 \mathrm{a} \pm 1.53$ & $1.500 \mathrm{ab} \pm 1.50$ & $5.333 \mathrm{ab} \pm .2 .73$ & $25.67 \mathrm{a} \pm .0 .0$ \\
NS-Farakoba & $2.333 \mathrm{a} \pm 1.20$ & $2.000 \mathrm{ab} \pm 1.00$ & $7.000 \mathrm{ab} \pm .2 .00$ & $83.33 \mathrm{a} \pm .56 .0$ \\
NS 1 & $2.333 \mathrm{a} \pm 1.20$ & $2.333 \mathrm{ab} \pm 1.20$ & $7.000 \mathrm{ab} \pm .2 .00$ & $81.00 \mathrm{a} \pm .40 .0$ \\
Pobe local & $7.667 \mathrm{a} \pm 1.20$ & $3.667 \mathrm{ab} \pm 0.67$ & $14.000 \mathrm{ab} \pm .0 .58$ & $94.33 \mathrm{a} \pm .52 .0$ \\
Sanzi & $0.000 \mathrm{a} \pm 0.00$ & $0.000 \mathrm{a} \pm 0.00$ & $0000 \mathrm{a} \pm .000$ & $59.33 \mathrm{a} \pm .47 .0$ \\
Tiligre & $9.667 \mathrm{a} \pm 5.24$ & $4.000 \mathrm{ab} \pm 2.08$ & $10.333 \mathrm{ab} \pm .3 .84$ & $23.67 \mathrm{a} \pm .17 .0$ \\
TVU 1509 & $3.667 \mathrm{a} \pm 1.86$ & $2.000 \mathrm{ab} \pm 1.00$ & $5.333 \mathrm{ab} \pm .3 .38$ & $65.33 \mathrm{a} \pm .36 .0$ \\
TVX3236 & $3.000 \mathrm{a} \pm 1.53$ & $2.333 \mathrm{ab} \pm 0.67$ & $4.666 \mathrm{ab} \pm .0 .88$ & $53.33 \mathrm{a} \pm .28 .0$ \\
Mean \pm & $5.217 \pm 0.72$ & $2.814 \pm 0.28$ & $7.933 \pm 0.69$ & $58.57 . \pm .4 .42$ \\
\hline
\end{tabular}

Means in each column followed by the same letter(s) are not significantly different at $p \leq 0.01$ using Student -Newman - Kuels test. Values are mean of 3 replication.

\subsubsection{Number of Thrips Per Plant}

The Analysis of Variance (ANOVA) of thrips was not significant but the number of thrips shows a difference between the genotypes. The mean of thrips infestation across the genotypes was $5.217 \pm 0.720$. The minimum thrips count was zero and the maximum was 26 thrips per plant. All genotypes with thrips number greater than or equal to six (6) were considered as thrips-susceptible. The action threshold was set at six thrips per flower bud, a population density which insecticide application is justified so as to prevent further increasing density from causing economic damage (Nabirye et al., 2003). The genotypes were separated into two groups, the first group with thrips number higher than six thrips per genotype and the $2^{\text {nd }}$ group with a thrips number below six or lower than six. Thus, the variety KN1 was the most infested. It is followed by the variety Kvx165-14-1, Kvx780-1, Tiligré, Pobé local, Komcallé and KVx780-6. Amongst the resistant varieties TVU1509, TVX3236 and Sanzi (0 thrips) had the lowest number of thrips.

\subsubsection{Buds Abortion}

The number of buds' abortion was varied from one variety to another. the evaluation of the average of buds' abortion per line showed different results as indicated in table 2 . The analysis was statistically significant $\left(\mathrm{R}^{2}=0,576 ; \mathrm{P}<0.01\right)$. The genotypes have a higher number of aborted bud than the improved varieties.

After parameter the genotype (lines popularized in 2012) Tiligré and Nafi have the less lost number than Komcallé and Gourgou.

The genotypes (extension lines) KVX 780-1, KVX 780-3, KVX 780-6) but KVX 780-1 was the best. 


\subsubsection{Flowers Abortion}

The analysis was statistically significant $\left(\mathrm{R}^{2}=0.515 ; \mathrm{F}=1.923 ; \mathrm{Pr}>\mathrm{F}=0.039\right)$.

For resistant genotypes, Sanzi (0) had a few Flowers abortion than other resistant lines like TVx3236 (4.66), TVu1509 (5.33) and Moussa local (3.0).

Among the newly released lines, the genotype Komcalle (15.33) had the highest number of aborted flowers than the lines Tiligré (10.33), Nafi (5.33) and Gourgou (10.0).

Among genotypes in the process of extension Kvx780-3(6.0), KVX 780-1(9), KVX 780-6(9.33) was the best.

\subsubsection{Flowers Damages}

The percentage of genotypes tested ranged from 0 to $77 \%$ for flower damage and from 0 to $76 \%$ for stipule varieties. Thrips damage on flowers and stipules of genotypes KN1, Komcallé, wild cowpea Farako-ba were high. This is synonymous with very dark browning of flowers and stipulates its varieties. Contrary Sanzi had a zero attack percentage. Thus the browning of the flowers and stipules of the genotypes TVX3236 and TVU1509 remains very weak.

\section{Discussion}

The objective of this study was to identify sources of resistance to hedgehog thrips of some lines of cowpea by comparing the tested genotypes versus the three genotypes considered resistant (TVU1509, TVX3236 and Sanzi). Parameters such as the number of aborted flowers, the total number of thrips, the damage to flowers and stipules per genotype are relevant for the identification of thrips resistant varieties.

The results for the total number of thrips per genotype showed that the susceptible check, KN1 (14.3 thrips on average) was the most infested line. On the other hand, the resistant genotype checks TVU1509, TVX3236 and Sanzi had the lowest thrips population 3.66, 3, and 0 thrips respectively. The action threshold was set at six thrips per flower bud, a population density which insecticide application is justified in order to prevent further increasing density from causing economic damage (Nabirye et al., (2003). These results confirm the earlier work done by Singh, (1987), Salifu et al., (1988) and Dabiré et al (2002) who reported that these genotypes were resistant to the thrips population. According to IITA, (1982) the resistance of TVU1509 is due to antibiosis.

Among the genotypes (newly released lines in 2012) Nafi, Komcallé, Tiligré, Gourgou,the genotype Nafi was the least infested.

For genotypes (lines undergoing extension) KVx780-1, KVx780-3 and KVx780-6), the genotype $\mathrm{KVx} 780-3$ performs better than the others.

As for the old genotype (popularized varieties) KVx61-1, KVx404-8-1, KVx745-11P, $\mathrm{KVx} 165-14-1$, the KVx745-11P presented less population of thrips.

At the level of genotypes (local varieties), Moussa local, Donsin local, Pobé local, Moussa 
local had fewer thrips than the others. These results confirm the work of Dabiré (2002) who had tested without insecticide treatment several varieties of cowpea (Moussa local, Boussé local, Kaokin local, KVx 404-19-3J, KVx404-2J, KVx404-8- 1, Sanzi, TVx3236 and TVu1509) throughout Burkina Faso.

The results for the number of aborted flowers ranged from 0\% (Sanzi) to $100 \%$ (wild cowpea). It was $45.16 \%$ for the released genotypes in 2012 and $37.58 \%$ for varieties undergoing the release process. As for local varieties (Moussa local and Pobé local) it ranged from $33.33 \%$ to $70 \%$. In addition, the percentage of aborted flowers for this trial is $43.53 \%$. These results confirm the work of Ndoye et al., (1984) in Bambey, which showed that the damage of thrips is manifested by abortion and by the fall of the flower $(80.46 \%)$.

Out of the lines popularized in 2012 (Nafi, Komcallé, Tiligré, Gourgou), Nafi behaves better in terms of damage on flowers and stipules.

For varieties undergoing extension (KVx780-1, KVx780-3 and KVx780-6), the flowers and stipules of the variety $\mathrm{KVx} 780-6$ showed less damage than the others.

\section{Conclusion}

Our study allowed to know the status of twenty cowpea genotypes in the local germoplasm for their resistance to thrips. It may be able to advise some genotypes (Nafi) in areas of high infestation of thrips in Burkina Faso. Crossing between the Sanzi genotype, a better genotype but less productive, and the Komcallé genotype, which is very susceptible to thrips but a variety adapted and preferred by producers.

\section{Acknowledgement}

We sincerely acknowledge the Kirkhouse Trust for funding, the institute of Environment and Agricultural Research for providing the seeds and materials used for the experiment and the University of Ouagadougou for Ph.D. admission.

\section{References}

Alabi, O. Y., Odebiyi, J., \& Jackai, L. (2003). Field evaluation of cowpea cultivars (Vigna unguiculata [L.] Walp.) for resistance to flower bud thrips (Megalurothrips sjostedti Trybom) (Thysanoptera: Thripidae). International Journal of Pest Management, October-December 2003, 49(4), 287-291, 6P.

Balde, D. (1997) Optimisation de la protection insecticide de la culture du niébé en fonction de la zone écologique. Mémoire de fin d'études pour l'obtention du diplôme d'ingénieur des Travaux Agricoles (I.T.A). ENCR (Bambey), 57.

Balde, M., \& Diop, A. (1995). Rapport d'activité 1994/95 du service d'Entomologie Mil/ niébé. ISRAKNRA (Bambey). Dot. Multigr., 19.

Dabiré, L. C. B. (2002). Rapport technique sur l'évaluation, sans insecticide, de la performance des variétés améliorées de niébé en milieu réel et cartographie des besoins en traitements insecticides du niébé au Burkina Faso. Campagne 1992 et Bilan 1990-1992. 


\section{Macrothink}

Journal of Agricultural Studies

ISSN 2166-0379

2018, Vol. 6, No. 4

Dabire, L. C. B., BA, M. N., \& Ouedraogo, J. (2001). Gestion intégrée des insectes ravageurs du niébé. 3.

Ennin-Kwabiah, S., \& Osei-Bonsu, P. (1993). Management of cowpea, Soybean, and groundnut in tropical cropping systems. CRI crop management research training. Crop Management Guide, 36, 34.

Jackai, L. E. N., \& Singh, S. R. (1988). Screening techniques for host plant resistance to cowpea insect pests. Trop. Grain Legume Bull., 35, 2-18.

Murdock, L. L., Coulibaly, O., \& Higgins T. J. V. (2008). Cowpea. Edited by Chittaranjan Kole and Timothy C. Hall. Compendium of Transgenic Crop Plants: Transgenic Legume Grains and Forages.

Nabirye , J., Nampala, P., Kyamanywa, S., Ogenga-Latigo, M. W.,Wilson, H., \& Adipala, E. (2003). Determination of damage-yield relationship and economic injury levels of flower thrips on cowpea in eastern Uganda. Crop Science, 22, 911-915. Crop Protection Department, Makerere University, P.O. Box 7062, Kampala, Uganda

Ndoye, D., \& Diop, K. (1984). Principaux résultats entomologiques obtenus dans le cadre du projet CRSP/NIEBE au Sénégal en 1983. Dot. Ronéo 5P. https://doi.org/10.1016/S0261-2194(03)00086-3

Pasquet (1998). Morphological study of cultivated cowpea. Importance of ovule number and definition of cv gr Melanophthalamus. Agronomie, 18, 61-70. Inra/Elsevier, Paris.

Salifu, A. B., Hodgson, C. J., \& Singh, S. R. (1988). Mecanisme of resistance in cowpea (V. unguiculata (L.) Walp.) genotype, Tvx 3236 Trybom (Thysartoptera; Thripidae) 1 Ovipositional. Non preference: Tropical Pest Management.184.

Singh, S. R. (1987). Host plant resistance for cowpea insect pest management. Insect Sci. Appl., 8, 765-769. https://doi.org/10.1017/S1742758400022888

Singh, S. R., \& Allen, D. J. (1980). Pests, diseases, resistance and protection of Vigna unguiculata (L.) Walp. Advances in legumes science. R. J. Summerfield and H. A. Bunting. Eds. London: Royal Botanical Gardens, and Ministry of Agriculture, Fisheries and Food. 419-443.

TA, I. I. (1982). Le niébé : Manuel de formation .Série de manuel n².

\section{Copyright Disclaimer}

Copyright for this article is retained by the author(s), with first publication rights granted to the journal.

This is an open-access article distributed under the terms and conditions of the Creative Commons Attribution license (http://creativecommons.org/licenses/by/4.0/). 